\section{Research Square}

Preprints are preliminary reports that have not undergone peer review. They should not be considered conclusive, used to inform clinical practice, or referenced by the media as validated information.

\title{
Spectral Characteristic Of The Waters With Different Sizes Of Particles: Impact Of Hydrochemical Property And Land Use Type
}

\author{
Zelan Lv \\ Jiangxi Normal University \\ Peng Wang \\ Jiangxi Normal University \\ Caixia Yan ( $\nabla$ wysycx@foxmail.com ) \\ Jiangxi Normal University \\ Minghua Nie \\ Jiangxi Normal University \\ Xiaoying Xiong \\ Jiangxi Normal University \\ Mingjun Ding \\ Jiangxi Normal University
}

\section{Research Article}

Keywords: natural colloids, size, absorbance, fluorescence, land use, hydrochemical properties

Posted Date: March 2nd, 2022

DOI: https://doi.org/10.21203/rs.3.rs-1311736/v1

License: (1) This work is licensed under a Creative Commons Attribution 4.0 International License. Read Full License 


\section{Abstract}

Natural colloids (NCs) are heterogeneous mixtures of particles in the aquatic environments that are strongly influenced by land use and hydrochemical properties between terrestrial and aquatic environments. However, the relevant study was paid little attention to the difference among the waters with different sizes of particles (e.g., suspended particulate matter-SPM, NCs, and the truly dissolved phase). In this study, the spectral properties of these different waters were investigated from different land-use types in the Yuan River basin, China. Results of the UV-visible absorption spectral showed that with the particle size increased, the aromaticity, chromophoric dissolved organic matter, and humification degree of organic matter increased, while the condensation degree decreased. Data analysis from the fluorescence indices indicated that the source and the autochthonous feature of the truly dissolved water differed from that of NCs and SPM. Whereas the protein-like component was mainly combined with the relatively larger size of particles (i.e., SPM and NCs), especially in the downstream. Redundancy analysis revealed that the spectral characteristics of the water samples were strongly influenced by the hydrochemical parameters (>45\%) with comparison to land-use type (nearly $10 \%)$. Furthermore, the impact of land-use type on the spectral properties was differed between the large and small scale of the buffer strips and between the mainstream and the tributaries. And this effect was more significant on the fluorescence properties in the mainstream and the spectral properties for NCs than for SPM. The study helps to understand the biogeochemical effects of the waters with different particle sizes.

\section{Introduction}

Natural Colloids (NCs) are heterogeneous mixtures of particles and ubiquitous with at least one-dimensional between $1 \mathrm{~nm}$ and $1 \mu \mathrm{m}$ in the aqueous environment (Lead and Wilkinson, 2006). NCs not only impact the carbon cycle of the natural and anthropogenic water bodies (Derrien et al., 2019), but also act as the important sorbent carriers for a variety of pollutants (e.g., metal ions, organic pollutants, etc.) due to the abundant active functional group in the aqueous environment (Yan et al., 2015; Yan et al., 2020). NCs are polydisperse matters, consisting of both inorganic substances (e.g. metal oxides and clays) and organic substances (e.g. humic substances and biopolymers) (Worms et al., 2010). Moreover, the composition of NCs varied greatly among different particle sizes, that the fluorescence intensity of NCs decreased with the particle size increased (i.e. truly dissolved phase $>1-10 \mathrm{kDa}>10$ $100 \mathrm{kDa}>100 \mathrm{kDa}-0.7 \mu \mathrm{m}$ ) (Yan et al., 2018). Therefore, research on the characterization of NCs is always focusing and difficult in this field. In addition, as the important source of NCs, suspended particulate matter (SPM) also plays a vital role in the carbon cycle, and in determining the water quality and the migration and transformation of contaminants (Ellis et al., 2012; He et al., 2016; Liu et al., 2016). Hence, the study on the properties of SPM helps to understand the biogeochemistry and water quality in aquatic environments (Wang et al., 2020). In fact, much attention had been paid to the properties of NCs or SPM, but few studies focus on the difference in the properties of both NCs and SPM.

Currently, the methods of the identification and quantification for characterization of NCs are becoming maturing. Among them, UV-visible spectroscopy (UV-vis) is widely used for identifying the active components of chromophoric dissolved organic matter /Fluorescent dissolved organic matter (CDOM/FDOM) due to the fast detection and the low cost (Rosario-Ortiz and Korak, 2017). In addition, three-dimensional fluorescence spectroscopy (3DEEM) could map the organic matter of different sources and compositions, and could achieve the separation and quantification of NCs after combining some analytical methods (e.g., parallel factor analysis, PARAFAC) (Stedmon et al., 2003). As a result, it is extensively applied in the identification of NCs in water, sediment/soil, and biomass (Liu et al., 2019; Sankar et al., 2019). Moreover, spectroscopy technology has been considered an effective indicator for determining the source of NCs in water and water quality changes (Rinot et al., 2021; Tao et al., 2021).

Previous studies have demonstrated that the physicochemical properties of NCs are influenced by a variety of environmental factors, such as hydrodynamic conditions, land-use types, soil properties, etc. (Kothawala et al., 2015; Wang et al., 2018; Sankar et al., 2020). For a specific watershed, the land-use types especially impacted the composition and fate of NCs in water. The land-use types could change the physicochemical properties of the soils in the watershed, which would further impact the counterparts of the rainfall and water within the watershed (Li et al., 2020). For example, NCs in aquatic environments were mainly terrestrial sources, and NCs from the cultivated land had more terrestrial humic substances than those from forestland. The higher proportion of forest land in the watershed, the more terrestrial NCs during a long-term rainfall, and the higher the aromatic and humification of NCs in water within the watershed (Hosen et al., 2018). A similar phenomenon was also found for NCs from the wetland (Geller and Oceanography, 1986). In contrast, the NCs in waters influenced by anthropogenic land use were characterized with a higher protein-like substance due to point-source pollution, phytoplankton degradation, and tributary inputs (Shi et al., 2020). At present, spectroscopic techniques have been successfully used in the characterization of NCs and the relationship between soil and water under different land-use patterns. However, these studies mainly focus on the spectral properties of organic matter in waters passed through the filters (typically $0.45 \mu \mathrm{m}$ or $0.7 \mu \mathrm{m}$ ), and few studies pay attention to the differences between NCs and the truly dissolved phase.

Yuan River basin $\left(27^{\circ} 33^{\prime} \mathrm{N}-28^{\circ} 05^{\prime} \mathrm{N}, 113^{\circ} 54^{\prime} \mathrm{E}-114^{\circ} 37^{\prime} \mathrm{E}\right)$ originates from the northwest foot of Wugong Mountains and discharges into the Gan River, the main tributary of the biggest freshwater lake in China-Poyang Lake. Along the river, different landscapes are dominant in the different sections of the river. Detailly, the upstream region is dominant with forestland having many mines; the midstream region harbors a large reservoir water project; and the downstream region is mainly composed of the agricultural and chemical industrial bases with low flow and large sewage discharge (Figure 1). Due to the accelerated urbanization in recent years, the surface water pollution in this region increased, which has threatened the health of the surrounding residents and ecological safety (Xu et al., 2021). Additionally, the relative studies on the aquatic environment in the Yuan River basin were mainly focused on the traditional pollutants such $\mathrm{N}$ and $\mathrm{P}$, and less attention was paid to NCs and their carried pollutants.

Therefore, this study introduced UV-vis and 3DEEMs-PARAFAC to characterize NCs and the truly dissolved phase from the main and tributaries of Yuan River. The aims of this study are to: 1) explore the impact of land use type on the spectral properties of NCs; 2) ascertain the difference of the 
fluorescence feature between different water phases containing different particle sizes (i.e., SPM, NCs, and the truly dissolved phase; 3 ) identify the influence factors (e.g., hydrochemical parameters) on the fluorescence properties. The results could provide a theoretical basis for pollution control in the study area.

\section{Materials And Methods}

\subsection{Sample collection and land use types}

In this study, sixteen and twenty-two sampling sites were collected from the mainstream ("M") (upstream Y01-Y05, midstream Y06-Y10, downstream Y11Y16) and the tributaries ("T") (T01-T22) of Yuan River in January 2020, respectively (Figure 1). Figure 1 also shows the land-use types in the watershed. The land-use data of Yuan River watershed obtained from $30 \mathrm{~m}$ resolution Landsat 8 data from 2017, which was provided by the National Science and Technology Infrastructure Platform-National Earth System Science Data Sharing Service Platform (http://www.geodata.cn). Different land-use types in the study area were extracted as cropland, forestland, grassland, water, residential land, others (such as bare lands and wetland, etc.) (Xu et al., 2021), and the "other" was excluded in the subsequent analyses due to the small portion of these land-use types accounted for less than $1 \%$ of the total catchment. Furthermore, $500 \mathrm{~m}$ and $1000 \mathrm{~m}$ buffer strips were respectively extended from each sampling site and considered as the small and large scale of the buffer zones. All the above analyses were operated by ArcGIS 10.2.

\subsection{Sample treatment}

After being transported to the laboratory, the water samples were filtered immediately through $0.45 \mu \mathrm{m}$ filter membranes (PVDF, Millipore, USA). Then a portion of the filtered water samples was used for hydrochemical parameters testing, and the rest proceeded for NCs separation. In this study, only the water samples from the mainstream were further isolated by a cross-flow ultrafiltration (CFUF). The filtrates $(<0.45 \mu \mathrm{m})$ were introduced into the CFUF system (Vivaflow50, Sartorius Stadium, Germany) containing a membrane molecular weight cut-off of $1 \mathrm{kDa}\left(\mathrm{PES}\right.$ membrane, $\left.5 \times 10^{3} \mathrm{~m}{ }^{2} \mathrm{PALL}, \mathrm{USA}\right)$, then NCs within the size ranged of $1 \mathrm{kDa}-0.45 \mu \mathrm{m}$ and the truly dissolved phase $(<1 \mathrm{kDa})$ were gained. A concentration factor $(c f)$ of 10 was chosen. The other information on ultrafiltration referred to our previous study (Yan et al., 2015).

\subsection{Hydrochemical parameters measurement}

The filtered water samples were subjected to the determination of the hydrochemical parameters. Dissolved organic carbon (DOC) concentrations were determined using liquiTOCII (Elementar, Germany). The concentrations of $\mathrm{NH}_{4}{ }^{+}, \mathrm{NO}_{2}{ }^{-}, \mathrm{NO}_{3}{ }^{-}$, and total phosphorus (TP) were determined using an automatic discontinuous analyzer (Smartchem 200, Brookfield, USA). While the concentration of $\mathrm{Na}^{+}, \mathrm{Mg}^{2+}, \mathrm{K}^{+}$, and $\mathrm{Ca}^{2+}$ were detected under an inductively coupled plasma-optical emission spectrometry (ICP-OES, Agilent, $\mathrm{USA}$ ). $\mathrm{Br}^{-}, \mathrm{Cl}^{-}, \mathrm{F}^{-}$, and $\mathrm{SO}_{4}{ }^{2-}$ were measured by an ion chromatography system (ICS-2100). And pH was measured using the $\mathrm{pH}$ meter (PHS-3C).

\subsection{Spectroscopic measurements}

All raw waters $(\mathrm{R})$, filtrates $(\mathrm{F})$, colloidal concentrates $(\mathrm{C})$, and ultrafiltrates $(\mathrm{U})$ were all processed to measure the spectral properties. The UV-Vis absorption spectra of all water samples were measured by UV-vis spectrophotometer (UV 3300, Meproda, Shanghai) with a $1 \mathrm{~cm}$ path-length quartz cell. The scan wavelength ranged from $200 \mathrm{~nm}$ to $800 \mathrm{~nm}$ at a resolution of $1 \mathrm{~nm}$. The absorbance of the Milli-Q water was taken as the baseline which was subtracted from the samples (Batchelli et al., 2009). Parallelly, all water samples were detected by a three-dimensional fluorescence spectrometer (F7100, HITACHI, Japan). The excitation wavelength (Ex) was 200-450 nm with increments of $5 \mathrm{~nm}$ and the emission wavelength (Em) was 250-500 nm with increments of $2 \mathrm{~nm}$. The scanning speed was $12000 \mathrm{~nm} \mathrm{~min}{ }^{-1}$ and the slit width was $5 \mathrm{~nm}$. Milli-Q water was used as blank before the measurement, and all samples were diluted when necessary to avoid the inner-filter effect by detecting the absorbance lower than 0.3 at $254 \mathrm{~nm}$ (Ohno, 2002 ).

\subsection{Data analysis}

\subsubsection{UV-vis parameters}

$\mathrm{UV}_{254}$, the absorbance at a wavelength of $254 \mathrm{~nm}$, is used to indicate the DOC concentration and the aromaticity (Nishijima and Speitel, 2004). The absorption coefficients at the corresponding wavelengths can be calculated according to the following equation, and the relative concentration of CDOM can be expressed as $\mathrm{a}_{355}$ (Zhang et al., 2005).

$$
\alpha_{\lambda}=2.303 A_{\lambda} / L
$$

where $a_{\lambda}$ and $A_{\lambda}$ represents the absorption coefficient and absorbance at wavelength $\lambda\left(m^{-1}\right)$, and $L$ is the path-length (m). 
E2/E4 is the ratio of absorbance at wavelengths of $254 \mathrm{~nm}$ and $436 \mathrm{~nm}$, which indicates the source of DOM. Moreover, E2/E4 also refers to the degree of molecule condensation of organic matters, and it increases as the E2/E4 value decreases (Strobel et al., 2001). E3/E4 is the absorbance ratio at 300 nm and $400 \mathrm{~nm}$, which represents the degree of CDOM humification; the higher the value, the lower the degree of CDOM humification(Artinger et al., 2000).

\subsubsection{Fluorescence index}

$\mathrm{Fn}_{280}$ and $\mathrm{Fn}_{355}$ indicate the relative concentration of protein-like and humic-like substances in DOM respectively. Fn 280 defined as the maximum fluorescence intensity of $\mathrm{Em}=340-360 \mathrm{~nm}$ at $\mathrm{Ex}=280 \mathrm{~nm}$, while $\mathrm{Fn}_{355}$ refers to the maximum fluorescence intensity of Em $=440-470 \mathrm{~nm}$ at $\mathrm{Ex}=355$ nm (Zhang et al., 2009).

In this study, fluorescence indices were introduced to further understand the differences in the sources and properties of the water samples in the Yuan River basin (Huguet et al., 2010). Fluorescence index (FI) describes the source of NCs and is defined as the ratio of fluorescence intensity at Em $=450 \mathrm{~nm}$ to that at $\mathrm{Em}=500 \mathrm{~nm}$ when $\mathrm{Ex}=370 \mathrm{~nm}$. FI > 1.9 and $\mathrm{FI}<1.4$ indicate NCs mainly microbial and terrestrial sources (McKnight et al., 2001). The biological index (BIX) characterizes the autogenous properties of NCs. It is defined as the ratio of the fluorescence intensity at Em $=380 \mathrm{~nm}$ to that at Em $=430 \mathrm{~nm}$ when $\mathrm{Ex}=310 \mathrm{~nm}$. The higher $(>1)$ the BIX value, the higher the autochthonous contribution, the greater the contribution of protein-like component and the higher the bioavailability (Wilson and Xenopoulos, 2009); the lower the value (0.6-0.7), the less the colloidal autochthonous components and the greater the terrestrial input or human influence (Huguet et al., 2009). Humification index (HIX), which represents the degree of humification of NCs, was first proposed by Zsolnay (Zsolnay et al., 1999). It is defined as the ratio of the peak areas of the corresponding regions when $\mathrm{Ex}=254 \mathrm{~nm}, \mathrm{Em}=435-480 \mathrm{~nm}$, and Em = 300-345 nm. The higher HIX value indicates a higher degree of humification (Birdwell and Valsaraj, 2010).

\subsubsection{Parallel factor analysis (PARAFAC)}

PARAFAC was used to extract the fluorescent components based on the 3D-EEMs of all samples. Before modeling, the raw data were corrected for Raman and Rayleigh scattering by MATLAB 2013 software (Zepp et al., 2004). Moreover, the fluorescence intensity of all samples was normalized to Raman units (r.u.) using the area of the Raman scattering peak of Milli-Q water at Ex $=350 \mathrm{~nm}$ (Lawaetz and Stedmon, 2009). Then all the data in the study were analyzed and validated by the DOMFluor toolbox of MATLAB 2013 (Stedmon et al., 2003). The final number of components was determined by split-half analysis, residual analysis, and loading analysis after removing some outliers. The fluorescence intensity at the fluorescence peak ( $F_{\text {max }}$, r.u.) is considered as the concentration of the fluorescent component (Osburn et al., 2011). Fluorophore identification of the output PARAFAC components was performed by the OpenFluor online database (Murphy et al., 2014).

\subsubsection{Other data analysis}

Principal component analysis (PCA) for the hydrochemical parameters and different analysis of the hydrochemical parameters and spectral parameters in the Yuan River basin are all performed in SPSS 19.0 (including $t$-test and ANOVA). Based on the hydrochemical parameters or land-use types data as the explanatory variable and the spectral parameters as the response variable, redundancy analysis (RDA) was conducted in Origin 2021 to explore the influencing factors of spectral parameters for the water bodies in the Yuan River basin. Besides, the spatial distribution of the fluorescence components and the distribution of the sampling sites were drawn in Arcgis 10.2.

\section{Results And Discussions}

\subsection{Characteristics of land-use and the hydrochemical parameters in Yuan River Basin}

The primary proportion of the land-use types in the Yuan River watershed is cropland and forestland, which accounts for $45.56 \%-55.20 \%$ and $11.34 \%-27.35 \%$, respectively, and grassland had the least proportion of $2.83 \%-4.52 \%$ (Table S1). In the $500 \mathrm{~m}$ buffer strips (small scale), the proportion of water was significantly higher in the mainstream than that in the tributaries. In the $1000 \mathrm{~m}$ buffer strips (large scale), the proportion of cropland in the mainstream decreased significantly (about 9\%), while the proportion of forestland increased dramatically (about 12\%). A similar trend with a smaller increase amplitude compared to those in the mainstream was also found in the tributaries. This is because the sampling sites in the tributaries are predominantly located in the mountainous area so that there is a smaller change of land use between small and large scales compared to those in the mainstream. The residential land, which is closely related to human activities, showed a lower proportion (3\%) at the large scale in the mainstream in comparison of the small scale; in contrast, the counterparts showed a slight increase (1\%) at the large scale in the tributaries than that at the small scale.

The hydrochemical parameter values of water samples (filtered water) in the mainstream and tributaries of the Yuan River basin are shown in Figure S1. The results showed that the water samples in the Yuan River basin were circumneutral to weakly alkaline $(\mathrm{pH}=6.78-8.34)$, with a low concentration of TP (0.04-0.48 $\left.\mathrm{mg} \mathrm{L}^{-1}\right)$ and DOC (4.82-25 mg L-1). For the positive ions, the concentrations of $\mathrm{Na}^{+}, \mathrm{Mg}^{2+}, \mathrm{K}^{+}, \mathrm{Ca}^{2+}$, and $\mathrm{NH}_{4}^{+}{ }^{\text {were }} 1.77-18.23 \mathrm{mg} \mathrm{L}^{-1}, 1.57-$ $13.99 \mathrm{mg} \mathrm{L}^{-1}, 1.17-10.35 \mathrm{mg} \mathrm{L}^{-1}, 9.68-80.97 \mathrm{mg} \mathrm{L}^{-1}$, and 0-1.99 $\mathrm{mg} \mathrm{L}^{-1}$, respectively, with the highest concentration for Ca ${ }^{2+}$. While for the negative ions, the concentrations of $\mathrm{Br}^{-}, \mathrm{Cl}^{-}, \mathrm{F}^{-}$, and $\mathrm{SO}_{4}{ }^{2-}$ were $0-0.11 \mathrm{mg} \mathrm{L}^{-1}, 1.39-41.69 \mathrm{mg} \mathrm{L}^{-1}, 0.10-1.66 \mathrm{mg} \mathrm{L}^{-1}$, and 3.97-81.49 mg L-1, respectively, with the highest concentration for $\mathrm{SO}_{4}{ }^{2-}$. According to the Environmental Quality Standards for Surface Water (GB3838-2002), the water quality of the Yuan River watershed was Class II water, except for TP and $\mathrm{NH}_{4}{ }^{+}$in some sampling sites exceeding the Class III water standard (e.g., TP concentration for T10, and 
TP and $\mathrm{NH}_{4}{ }^{+}$concentration for T14). Notably, the pollution of phosphorus should still be paid more attention to. Based on the $t$-test analysis, only pH, $\mathrm{DOC}, \mathrm{Na}^{+}, \mathrm{Ca}^{2+}$, and $\mathrm{Br}^{-}$showed statistically significant differences between the mainstream and the tributaries. Namely, the relatively higher concentrations of $\mathrm{Na}^{+}$and $\mathrm{Br}^{-}$are observed in the mainstream, and the relatively higher concentrations of $\mathrm{pH}, \mathrm{DOC}$, and Ca ${ }^{2+}$ are detected in the tributaries. These results indicated that there's not much difference in the hydrochemical parameter values between the mainstream and the tributaries. It is worth noting that DOC concentrations, which usually showed a higher correlation with the spectral properties of water samples, are higher in tributaries, suggesting that the pollution in tributaries may be worse than that in the mainstream, but further verification is needed. Additionally, PCA was introduced to explore the contamination characteristics of the 14 hydrochemical parameters (KMO $=0.542, \mathrm{P}<0.001$ ), and 6 principal components were sufficient to explain the characterization with the total explanation high of $86.2 \%$. Thereinto, the higher weighting was related to $\mathrm{Cl}^{-}, \mathrm{Ca}^{2+}, \mathrm{DOC}^{-} \mathrm{F}^{-}, \mathrm{Mg}^{2+}$ and $\mathrm{NO}_{2}{ }^{-}$, suggesting that the pollution of the Yuan River basin was mainly attributed to these parameters.

\subsection{Spectral indices of water samples in the Yuan River basin}

\subsubsection{UV-vis parameters of water samples in the Yuan River basin}

The UV-vis parameters (including $\mathrm{UV}_{254}, \mathrm{a}_{355}, \mathrm{E} 2 / \mathrm{E} 4$, and E3/E4) values of the raw and filtered water in the mainstream and tributaries of the Yuan River basin are shown in Figure 2A. The $U_{254}$ value of the raw water was $0.049 \pm 0.009$ in the mainstream and $0.066 \pm 0.043$ in the tributaries; and the counterparts of the filtered water were $0.036 \pm 0.011$ in the mainstream and $0.040 \pm 0.020$ in the tributaries, respectively. The $a_{355}$ value of the raw water was $3.680 \pm 0.842$ in the mainstream and $6.144 \pm 5.456$ in the tributaries; and the counterparts of the filtered water were $2.880 \pm 0.897$ in the mainstream and $3.611 \pm 1.725 \mathrm{~m}^{-1}$ in the tributaries, respectively. The E2/E4 ratio of the raw water was $6.43 \pm 2.04$ in the mainstream and $5.88 \pm 2.01$ in the tributaries; and the counterparts of the filtered water were $16.65 \pm 6.54$ in the mainstream and $11.77 \pm 8.25$ in the tributaries, respectively. The E3/E4 ratio of the raw water was $2.39 \pm 0.40$ in the mainstream and $2.37 \pm 0.46$ in the tributaries; and the counterparts of the filtered water were $1.78 \pm 0.30$ in the mainstream and $1.79 \pm 0.51$ in the tributaries, respectively.

According to the results of different analyses, there were no significant differences between the mainstream and the tributaries for all the four UV-vis parameters in both raw and filtered water. This result indicated that the aromaticity, CDOM concentration, the condensation degree of the molecular, and the humification of the organic matter make little difference between the mainstream and the tributaries in the Yuan River basin. However, there was a significant difference between the raw and filtered water for all the four UV-vis parameters. That is, the value of UV $254, a_{355}$, and E3/E4 was relatively high in the raw water, and a higher ratio of E2/E4 was detected in the filtered water. These results suggested that the organic matter in SPM (>0.45 $\mu \mathrm{m}$ ) could not be ignored which made the aromaticity, CDOM concentration, and the humification degree of the organic matter higher in the raw water. Whereas the condensation degree of the molecular in SPM was lower than NCs which resulted in the lower condensation degree of the molecular in the raw water.

The distribution characteristics of the four UV-vis parameters in different water samples (including raw water, filtered water, and ultrafiltered water) of the mainstream were further analyzed in this study (Figure 2B). The results showed that except for E2/E4, the average values of the other three parameters all showed a descending order as follows: raw water > filtered water > ultrafiltrates. The results of ANOVA showed that the UV $254, a_{355}$, and E3/E4 values of the raw water were significantly higher than those of the filtered water and ultrafiltrates. On the contrary, the highest value of E2/E4 was found in ultrafiltrates and significantly higher than those in raw and filtered water. The results indicate that with the particle size increased, the aromaticity, CDOM concentration, and humification degree of organic matter increased, and the condensation degree decreased.

\subsubsection{Fluorescence indices of water samples in the Yuan River basin}

$\mathrm{Fn}_{280}$ and $\mathrm{Fn}_{355}$ was the indicator of the concentration of the protein-like and the humic-like substances, respectively. In the Yuan River basin (Figure $3 \mathrm{~A}$ ), $\mathrm{Fn}_{280}$ value of the raw water was $0.18 \pm 0.05$ r.u. in the mainstream and $0.18 \pm 0.06$ r.u. in the tributaries; and the counterparts of the filtered water were $0.17 \pm 0.07$ r.u. in the mainstream and $0.20 \pm 0.10$ r.u. in the tributaries, respectively. While $\mathrm{Fn}_{355}$ value of the raw water was $0.12 \pm 0.02$ r.u. in the mainstream and $0.14 \pm 0.06$ r.u. in the tributaries; and the counterparts of the filtered water were $0.12 \pm 0.03$ r.u. in the mainstream and $0.13 \pm 0.06$ r.u. in the tributaries, respectively. These results revealed that: 1) the concentration of protein-like substances in the Yuan River basin is significantly higher than that of humic-like substances; 2) the concentration of the fluorescent substances in water samples from the tributaries are similar to those from the mainstream; 3) the concentration of the protein-like and the humic-like substances in raw and filtered water made no significant difference. Moreover, the results 2) and 3) were verified by the statistical test that no significant difference of $\mathrm{Fn}_{280}$ and $\mathrm{Fn}_{355}$ values were found between the mainstream and the tributaries and between the raw water and the filtered water. In other words, the protein-like and humic-like substances of the water samples in the mainstream and the tributaries made few differences, and the concentration of the fluorescent substances in SPM were low which were primarily exist in the filtered water. Figure S2 displays the spatial distribution of $\mathrm{Fn}_{280}$ and $\mathrm{Fn}_{355}$ values in the Yuan River basin. Results showed that both two indices were generally increased along the water flow direction, suggesting the higher fluorescent substance and the worse water pollution of the downstream in Yuan River basin.

$\mathrm{Fn}_{280}$ values of the raw water, filtered water, and ultrafiltrates in the mainstream of Yuan River were $0.18 \pm 0.05$ r.u., $0.17 \pm 0.07$ r.u., and $0.14 \pm 0.05$ r.u.; and $\mathrm{Fn}_{355}$ values of the raw water, filtered water, and ultrafiltrates in the mainstream were $0.12 \pm 0.02$ r.u., $0.12 \pm 0.03$ r.u., and $0.11 \pm 0.03$ r.u., respectively (Figure $3 \mathrm{~B})$. These results showed that the concentrations of the protein-like and humic-like substances were similar for the raw and filtered water, and then 
slightly decreased from the filtered water to ultrafiltrates. Unfortunately, no significant difference was found among these water samples, which might be attributed to the low concentration of NCs in the filtered water so that there is no significant difference of fluorescent substances between the filtered water and the truly dissolved water (i.e., ultrafiltrates) (Xu et al., 2018).

To gain insight into the source and compositions of the fluorescence components in the different size waters from the Yuan River basin, three fluorescence indices (i.e., FI, HIX, and BIX) were introduced to characterize the sources, humification, and authigenic properties of organic matter in the waters with different size of particles, and the results are shown in Figure 3. FI values of the raw water, filtered water, and ultrafiltrates in the mainstream of Yuan River were $1.52 \pm 0.05,1.48 \pm 0.05$, and $1.52 \pm 0.03$, respectively; FI values of the raw and filtered water in the tributaries were very close $(1.40 \pm$ 0.05). Combined with Figure S3 which showed the fluorescence indices distribution of water samples, the FI values of all water samples in both mainstream and tributaries were generally lower than 1.5 , suggesting that the organic matter in water in the Yuan River basin were mainly a terrestrial source with a small contribution of autogenous productivity and microbial activity. Different analyses indicated that there were no statistically significant differences of FI values between mainstream and tributaries, as well as the raw and filtered water in mainstream and tributaries. Based on the above discussion that the fluorescent substances were dominant in the filtered water, it could result in a similar source of the fluorescent substances in raw and filtered water. However, a significant difference of FI value was found between the raw / filtered water and the ultrafiltrates, indicating that the source of the fluorescent substances in SPM / NCs and the truly dissolved water were the essential differences.

HIX values of the raw water, filtered water, and ultrafiltrates in the mainstream of Yuan River were $3.39 \pm 0.59,3.83 \pm 0.65$, and 3.88 \pm 1.03 , respectively; $\mathrm{HIX}$ values of the raw and filtered water in the tributaries were $3.55 \pm 0.79$ and $3.83 \pm 1.21$, respectively. Combined with Figure S3, the HIX values in this study were overall lower than 6 , suggesting the low humification degree of the organic matter in the Yuan River basin. Different analyses showed that there were no statistically significant differences of HIX values between mainstream and tributaries and between the raw and filtered water both in mainstream and tributaries, revealing that it made little difference of the humification degree of the fluorescent substance between mainstream and tributaries, and between SPM and NCs. Besides, there was a statistical difference between the raw water and ultrafiltrates in the mainstream, which meant that the humification degree of organic matter in SPM and the truly dissolved phase made an obvious difference, i.e., the higher value humification degree of samples was related to the truly dissolved water. Whereas, this difference was not observed between the filtered water and the ultrafiltrates, indicating that the humification degree of NCs was somewhere in-between SPM and the truly dissolved water.

$\mathrm{BIX}$ values of the raw water, filtered water, and ultrafiltrates in the mainstream of Yuan River were $0.84 \pm 0.07,0.87 \pm 0.10$, and $0.94 \pm 0.21$, respectively; BIX values of the raw and filtered water in the tributaries were $0.84 \pm 0.10$ and $0.80 \pm 0.04$, respectively. Combined with Figure S3, the BIX values in this study were general ranged from 0.8 to 0.9 , demonstrating that the organic matter in the water samples was primarily terrestrial input or human influence with a mixture of some autochthonous sources in the Yuan River basin. The results of different analyses of BIX values were consistent with those of FI values, indicating that: 1) the contribution of the autochthonous origin for water samples was similar between the mainstream and the tributaries, as well as SPM and NCs; 2) the contribution of the autochthonous origin in the truly dissolved water was higher than those in SPM and NCs.

In comparison to the literature, the fluorescence indices of the waters in the Yuan River basin were in the range of the values reported in other waters (Table S2). For example, the FI values in this study were slightly lower than those in Dian Lake (1.5-1.7), while much lower than those in Chao Lake (1.602.40), indicated that the higher possibility of terrestrial source for the waters in Yuan River basin. Similarly, the HIX values in this study were also not high and in accordance with those in the rural watersheds and Chao Lake demonstrated that the lower degree humification of waters in the Yuan River basin. Due to the various waters (i.e., raw water, filtered water, and ultrafiltrates) were selected in this study, the BIX values span a relatively large range which was agreed with those in other waters.

\subsection{Distribution of the fluorescence components of water samples in the Yuan River basin}

\subsubsection{PARAFAC component characteristics}

Based on the PARAFAC model, three fluorescent components were extracted from the water samples in the Yuan River watershed, including one humiclike fluorescent component (C1) and two protein-like fluorescent components (C2 and C3) (Figure S4). The maximum Ex/Em wavelengths of the fluorescence peaks are 245/430 nm (C1), 225(275)/330 nm (C2), and 235(300)/350 nm (C3), respectively. A comparison with the online OpenFluor database showed (Table S3) that the Tucker convergence coefficient (TCC) values, which represents the matching degree between the component in this study and the published model, were all higher than 0.98, indicating that the fluorescent components in Yuan River watershed are all common fluorescent substances in the environment. The $\mathrm{C} 1$ component resembles the traditional humic-like substance (Zhou et al., 2021), and the excitation and emission characteristics were usually associated with the terrestrial organic matter which was composed of high molecular weight and aromatic organic compounds (Kowalczuk et al., 2009). C2 component is a protein-like substance, which could be used to predict the degree of contamination in water bodies (Zhu et al., 2015). C3 component is also a protein-like substance, which mainly planktonic degraded tryptophan-like class authigenic substances.

\subsubsection{Distribution of fluorescence components of water samples in Yuan River basin}


The distribution of the three fluorescent components in the Yuan River basin is shown in Figure 4. The fluorescence intensity of $\mathrm{C} 1$ component in the raw water, filtered water, and ultrafiltrates in the mainstream was $0.35 \pm 0.07$ r.u., $0.35 \pm 0.07$ r.u., and $0.30 \pm 0.09$ r.u., respectively; and the fluorescence intensity of $\mathrm{C} 1$ component in the raw and filtered water in tributary were $0.38 \pm 0.15$ r.u. and $0.36 \pm 0.14$ r.u., respectively. The fluorescence intensity of $\mathrm{C} 2$ component in the raw water, filtered water, and ultrafiltrates in the mainstream were $0.34 \pm 0.07$ r.u., $0.29 \pm 0.11$ r.u., and $0.21 \pm 0.06$ r.u., respectively; and the fluorescence intensity of $\mathrm{C} 2$ component in the raw and filtered water in tributary were $0.36 \pm 0.11$ r.u. and $0.39 \pm 0.21$ r.u., respectively. The fluorescence intensity of $\mathrm{C} 3$ component in the raw water, filtered water, and ultrafiltrates in the mainstream was $0.14 \pm 0.04$ r.u., $0.16 \pm 0.10$ r.u., and $0.13 \pm 0.05$ r.u., respectively; and the fluorescence intensity of C3 component in the raw and filtered water in tributary were $0.13 \pm 0.06$ r.u. and $0.13 \pm 0.06$ r.u., respectively. The fluorescent intensity of the three components was ordered as follows: $\mathrm{C} 1 \approx \mathrm{C} 2>\mathrm{C} 3$, revealing that the protein-like substances are dominant fluorophores of the water samples in the Yuan River basin. It has been reported that the protein-like substances were an indicator of water pollution, i.e., the higher concentration of the protein-like substances, the worse the water quality (Meng et al., 2013). Therefore, the water quality of Yuan River might be not good and needs to be paid more attention to. Results of the different analyses indicated that the significant difference was only observed for the $\mathrm{C} 2$ component between the raw / filtered water and the ultrafiltrates, which confirmed that the protein-like component was mainly combined with the relatively larger size of particles (i.e., SPM and NCs) rather than the truly dissolved water, which is consistent with the results in previous studies (Trubetskoj et al., 2018).

The proportion of C1-C3 components in the Yuan River basin is displayed in Figure 5. The proportion of C1 component in the raw water, filtered water, and ultrafiltrates in the mainstream were $42.41 \pm 4.42 \%, 44.65 \pm 5.00 \%$, and $45.82 \pm 9.09 \%$, respectively; and the proportion of $\mathrm{C} 1 \mathrm{component}$ in the raw and filtered water in tributary were $42.76 \pm 7.10 \%$ and $42.99 \pm 9.82 \%$, respectively. The proportion of $\mathrm{C} 2$ components in the raw water, filtered water, and ultrafiltrates in the mainstream were $41.65 \pm 3.89 \%, 36.26 \pm 4.93 \%$, and $33.73 \pm 5.64 \%$, respectively; and the proportion of $\mathrm{C} 2$ components in the raw and filtered water in tributary were $42.16 \pm 6.43 \%$ and $42.57 \pm 11.22 \%$, respectively. The proportion of C3 components in the raw water, filtered water, and ultrafiltrates in the mainstream were $15.94 \pm 3.37 \%, 19.09 \pm 5.29 \%$, and $20.45 \pm 5.51 \%$, respectively; and the proportion of C3 components in the raw and filtered water in tributary were $15.09 \pm 4.36 \%$ and $14.44 \pm 2.72 \%$, respectively. Obviously, the proportion of C1 was the highest (average, $43.13 \%$ ), followed by C2 (average, 40.76\%), and C3 (average, 16.11\%) had the lowest proportion. Different analyses revealed that the significant difference was only found for the proportion of $\mathrm{C} 2$ between the raw water and the filtered water / ultrafiltrates in the mainstream, suggesting that the protein-like substance in SPM was significantly higher than those in NCs or the truly dissolved water. And combined with the results of the fluorescence intensity of the components, the protein-like substance in NCs was more than that in the truly dissolved water, yet lower than those in SPM, which might be attributed to the low concentration of NCs in waters.

The spatial distribution of the concentration and proportion of the three fluorescence components in mainstream and tributaries from the Yuan River basin is shown in Figure S5. It can be seen that the distribution of the fluorescent components from the upstream to the downstream both in the mainstream and tributaries changed slightly. In further, a different analysis of the fluorescent components among the upstream, midstream, and downstream of the Yuan River basin was made. It found that there was a significant difference of C3 component between the upstream and the downstream for both raw and filtered water in the mainstream ( $P=0.010$, raw water; $P=0.025$, filtered water). In addition, the obvious difference of the $\mathrm{C} 2$ component in raw water of the mainstream between the upstream and the downstream was also detected $(P=0.029)$. In the tributaries, only the $\mathrm{C} 2$ component in raw water was significantly different between the upstream and the downstream of the river $(P=0.015)$. The concentrations of the fluorescent components in the upstream, midstream, and downstream are shown in Table 1. Results showed that the concentration of both $\mathrm{C} 2$ and $\mathrm{C} 3$ components was higher in the downstream neither the mainstream nor the tributaries, and neither the raw water nor the filtered water. These results demonstrated that the protein-like components were higher in downstream, illustrating the worse water quality of downstream of the river.

However, the differences in the proportion of the fluorescent components among different parts of the river were not consistent with the concentration of the fluorescent components' distribution. Although no significant difference in the concentration of C1 components among different parts of Yuan River, a relatively higher proportion of $\mathrm{C} 1$ components in the midstream was found both in the filtered water and the ultrafiltrates in the mainstream, indicating that the humic-like substance was mainly present in the small size of particles (i.e., NCs and the truly dissolved water), which might be on account of the higher proportion of water in the midstream. Previous studies had shown that terrestrial humic-like substances were often derived from the decomposition of plant litter and soil, or microbial metabolism and high microbial activity in the water bodies (Huang et al., 2015; Zhao et al., 2018). Due to the high proportion of the humic-like substances in midstream, the proportion of the protein-like components was reduced, especially for C2. Instead, a significantly higher proportion of $\mathrm{C} 2$ in the upstream was found than those in the midstream both in the filtered water and the ultrafiltrates in the mainstream. While the proportion of $\mathrm{C} 3$ in downstream (in the raw and filtered water) was obviously higher than that in the upstream. These results demonstrated that C2 and C3 was the protein-like substance sourced differently and C3 might be an indicator of water pollution. In the tributaries, the significant differences of all fluorophores were only found for the filtered water between the midstream and the downstream, i.e., the proportion of $\mathrm{C} 1$ and C3 was higher in the downstream, and the proportion of C2 was higher in the midstream. This different proportion of the fluorescent components among the different sections of the river in the mainstream and the tributaries might be because of the difference of the land use from the mainstream to the tributaries. In the midstream, the sampling sites of the land use type in the mainstream and the tributaries were water and residential land, while the counterparts in downstream were residential land and cropland. But the impact of land-use types on the distribution of the fluorescent components in the Yuan River basin was need further study.

3.4 Redundancy Analysis (RDA)

\subsubsection{Interpretation by the hydrochemical parameters}


RDA was processed to explore the impact of the hydrochemical parameters on the spectral characteristics of the water samples in the Yuan River basin (Figure S6). The total explanation of all the hydrochemical parameters for the spectral parameters in the raw and filtered water was $75.30 \%$ and $45.95 \%$, respectively. The explanation for the first and second axes in the raw water samples was $68.82 \%$ and $5.74 \%$; and the corresponding explanations in the filtered water samples were $45.06 \%$ and $0.55 \%$, respectively. These results illustrated that the spectral characteristics of the water samples were influenced by the hydrochemical parameters to some extent. As Figure S6 shown, the black and red arrows in the figure represent the hydrochemical parameters and the spectral parameters, respectively; and the cosine value of the angle between them represents their correlation. It could be seen that the relative higher eigenvalues were observed for $\mathrm{Cl}^{-}, \mathrm{DOC}, \mathrm{Mg}^{2+}, \mathrm{K}^{+}$, and $\mathrm{NO}_{3}{ }^{-}$, and a higher positive correlation was found between them; in contrast, $\mathrm{Ca}^{2+}, \mathrm{NO}_{2}{ }^{-}$and $\mathrm{F}^{-}$showed the higher eigenvalues in the opposite direction of the former hydrochemical parameters either in the raw water or in the filtered water. It indicated that these parameters greatly influenced the spectral parameters. In addition, the results that these hydrochemical parameters had higher eigenvalues were in accordance with those in PCA. Specifically, E2/E4 and E3/E4 in raw water were positively correlated with $\mathrm{NO}_{2}{ }^{-}$and $\mathrm{SO}_{4}{ }^{2-}$, and $\mathrm{a}_{355}, \mathrm{C} 1, \mathrm{HIX}$, and $\mathrm{Fn}_{355}$ values were positively correlated with DOC, $\mathrm{K}^{+}$, and $\mathrm{Cl}^{-}$. The $\mathrm{a}_{355}$ value in filtered water was positively correlated with TP and DOC, and E2/E4 was positively correlated with $\mathrm{F}^{-}$. These results revealed that the hydrochemical parameters strongly impacted the spectral characteristics of the water samples in the Yuan River basin.

\subsubsection{Interpretation of by land-use types}

The total explanation, as well as the explanation of the first and second axes of the spectral parameters by the land use types in the Yuan River basin are shown in Table 2. In general, the total explanation of the spectral parameters by land-use types was much less than by the hydrochemical parameters. It was differed according to the selected sampling sites (i.e., the mainstream, the tributaries, and the total river basin). Additionally, the explanation changed with the land-use types from the different distance buffer zones. For all the spectral parameters, the land-use types in the $500 \mathrm{~m}$ and $1000 \mathrm{~m}$ buffer strips explained $10.3 \%$ and $6.4 \%$ of the overall river watershed, respectively; and the corresponding explanation in the $500 \mathrm{~m}$ buffer strips (15.3\%) for the mainstream was higher than those for the total river basin, but the corresponding explanation in the $1000 \mathrm{~m}$ buffer strips (17.3\%) for the tributaries was relatively higher. These results indicated that the land use types at the small scale impacted greater on the spectral parameters in the mainstream, and more effective was obtained for the tributaries when the land use types in the buffer strips at the larger scale. Interestingly, this phenomenon was consistent with the higher percentage of residential land in the mainstream at small scales and in tributaries at large scales, implying the significant influence of human activities on the spectral characteristics of the water. It had been proved that the protein-like component could reflect the sewage disposal performance(Tao et al., 2021). In addition, the optical signature of DOM could reflect the developmental level of the city, i.e., the higher proteinlike component was found for the developed cities, whereas the humic-like component was high for the undeveloped cities (Shang et al., 2021).

Furthermore, the impact of the land-use types at the small and the large scale on the UV-vis and fluorescence characteristics of water was also studied. It was found that the explanation of the UV-vis parameters by the land use types both at the small and the large scale in both mainstream and tributaries was similar to the explanation of all the spectral parameters of the water samples in the Yuan River basin. These results suggested that the effect of land-use types on the spectral parameters of water is mainly featured as the UV-vis parameters, rather than the fluorescence parameters. Nevertheless, the explanation of the fluorescence parameters by the land use types at the small scale was higher than that of all the spectral parameters. In detail, the corresponding explanation both increased nearly $3 \%$ in the tributaries and the overall river basin and increased to $51 \%$ in the mainstream, revealing that the effects of the land use types on the fluorescence parameters of water were greater at the small scales, especially for the mainstream. In contrast, the explanation of the fluorescence parameters by the land use types at the large scale was decreased to a certain extent to $4.3 \%$ and $23.4 \%$ in tributaries and mainstream, respectively. This result confirmed that the influence of the land use types on the fluorescence parameters was more significant in the mainstream even at a large scale.

For the water samples with different sizes of particles, the explanation of all the spectral parameters by the land-use types at the two scales in the filtered water was higher than that in the raw water, indicating that the impact of land-use types on the spectral parameters for NCs was greater than that for SPM. In general, the land-use types at the small scale had a greater impact on spectral parameters compared to those at the large scale. Owing to the limitation of the number of sample sites, it could not obtain the explanation of the spectral parameters of the water samples by land use in the mainstream. But with combined the results in tributaries and the overall river basin, the effect of land-use types at a small scale on the spectral parameters of SPM was greater in the mainstream, and the corresponding effect on the spectral parameters of NCs was greater in tributaries; in contrast, the effects of land-use types at large scale on the spectral parameters of both SPM and NCs were greater in tributaries.

\section{Conclusions}

In this study, the effect of the hydrochemical properties and the land use type on the spectral characterization of the waters with different sizes of particles (i.e., SPM, NCs, and the truly dissolved water) were investigated in the Yuan River basin. In general, there was no significant difference in the spectral properties between the mainstream and the tributaries, but some important variations were observed among the waters with different sizes of particles. Results of UV-vis showed that the aromaticity, CDOM concentration, and the humification degree of the organic matter in SPM could not be ignored which had a lower condensation degree of the molecular than that of NCs. However, the fluorescence feature between SPM and NCs made little difference. The protein-like substance was the primary fluorescence with the relatively higher concentration in the waters with larger size particles in downstream. Although redundancy analysis revealed that the hydrochemical properties made more contribution to the spectral properties compared to the land use types, the hydrochemical properties were inevitably impacted by the land use types. In this sense, the spectral properties of the waters were 
strongly influenced by land use. Furthermore, human activities made a vital role in the spectral characteristics of the waters, especially for NCs. This study demonstrated that the hydrological properties and the land use type affect the spectral properties of the waters with different sizes of particles, and these results provide important data for the protection and prevention of the water in the Yuan River.

\section{Declarations}

\section{Author contribution}

Zelan Lv: Conceptualization, Methodology, Formal analysis, Execution, Writing - original draft.

Peng Wang: Methodology, Writing - review \& editing. Caixia Yan: Conceptualization, Methodology, Formal analysis, Writing - review \& editing. Minghua Nie: Conceptualization, Validation, Writing - review \& editing. Xiaoying Xiong: Methodology, Validation, Writing - review \& editing. Mingjun Ding: Conceptualization, Validation, Writing - review \& editing.

\section{Funding}

The work was supported by the National Natural Science Foundation of China (No. 42067058 and 42067034 ). Additional funding was provided by the Natural Science Foundation of Jiangxi Province (No. 20202BAB203015 and 20202BAB203014), the Training Project for Major Academic Disciplines and Technology Leader of Jiangxi Province (20212BCJL23058) and the Open Fund of Key Laboratory of Eco-geochemistry, Ministry of Natural Resources (ZSDHJJ202004).

\section{Data availability}

The authors declare that all relevant data supporting the findings of this study are included in this article and its supplementary information files.

Competing interests: The authors have no conflicts of interest to declare that are relevant to the work reported in this article.

Ethical approval and consent to participate: This work did not report on or involved the use of any animal or human data or tissue.

Consent to publish: This work did not contain data from any individual person.

\section{References}

1. Artinger R, Buckau G, Geyer S, Fritz P, Wolf M, Kim JI (2000) Characterization of groundwater humic substances: influence of sedimentary organic carbon. Appl Geochem 15:97-116. https://doi.org/10.1016/S0883-2927(99)00021-9

2. Batchelli S, Muller FLL, Baalousha M, Lead J, R (2009) Size fractionation and optical properties of colloids in an organic-rich estuary (Thurso, UK). Mar Chem 113:227-237. https://doi.org/10.1016/j.marchem.2009.02.006

3. Birdwell JE, Valsaraj KT (2010) Characterization of dissolved organic matter in fogwater by excitation-emission matrix fluorescence spectroscopy. Atmos Environ 44:3246-3253. https://doi.org/10.1016/j.atmosenv.2010.05.055

4. Derrien M, Brogi SR, Gonçalves-Araujo R (2019) Characterization of aquatic organic matter: Assessment, perspectives and research priorities. Water Res 163:114908. https://doi.org/10.1016/j.watres.2019.114908

5. Ellis EE, Keil RG, Ingalls AE, Richey JE, Alin SR (2012) Seasonal variability in the sources of particulate organic matter of the Mekong River as discerned by elemental and lignin analyses. J Geophys Res-Biogeo 117(G1):1038. https://doi.org/10.1029/2011jg001816

6. Geller AJL (1986) Comparison of mechanisms enhancing biodegradability of refractory lake water constituents 1. Limnol Oceanogr 31:755-764. https://doi.org/10.4319/lo.1986.31.4.0755

7. He W, Chen M, Park JE, Hur J (2016) Molecular diversity of riverine alkaline-extractable sediment organic matter and its linkages with spectral indicators and molecular size distributions. Water Res 100:222-231. https://doi.org/10.1016/j.watres.2016.05.023

8. Hosen JD, Armstrong AW, Palmer MA (2018) Dissolved organic matter variations in coastal plain wetland watersheds: The integrated role of hydrological connectivity, land use, and seasonality. Hydrol Process 32:1664-1681. https://doi.org/10.1002/hyp.11519

9. Huang W, McDowell WH, Zou X, Ruan H, Wang J, Ma Z (2015) Qualitative differences in headwater stream dissolved organic matter and riparian water-extractable soil organic matter under four different vegetation types along an altitudinal gradient in the Wuyi Mountains of China. Appl Geochem 52:67-75. https://doi.org/10.1016/j.apgeochem.2014.11.014

10. Huguet A, Vacher L, Relexans S, Saubusse S, Froidefond JM, Parlanti E (2009) Properties of fluorescent dissolved organic matter in the Gironde Estuary. Org Geochem 40:706-719. https://doi.org/10.1016/j.orggeochem.2009.03.002

11. Huguet A, Vacher L, Saubusse S, Etcheber H, Abril G, Relexans S, Ibalot F, Parlanti E (2010) New insights into the size distribution of fluorescent dissolved organic matter in estuarine waters. Org Geochem 41:595-610. https://doi.org/10.1016/j.orggeochem.2010.02.006

12. Kothawala DN, Ji X, Laudon H, Ågren AM, Futter MN, Köhler SJ, Tranvik LJ (2015) The relative influence of land cover, hydrology, and in-stream processing on the composition of dissolved organic matter in boreal streams. J Geophys Res-Biogeo 120:1491-1505.

https://doi.org/10.1002/2015JG002946 
13. Kowalczuk P, Durako MJ, Young H, Kahn AE, Cooper WJ, Gonsior M (2009) Characterization of dissolved organic matter fluorescence in the South Atlantic Bight with use of PARAFAC model: Interannual variability. Mar Chem 113:182-196. https://doi.org/10.1016/j.marchem.2009.01.015

14. Lawaetz AJ, Stedmon CA (2009) Fluorescence intensity calibration using the Raman scatter peak of water. Appl Spectrosc 63:936-940. https://doi.org/10.1366/000370209788964548

15. Lead JR, Wilkinson KJ (2006) Aquatic colloids and nanoparticles: current knowledge and future trends. Environ Chem 3:159-171. https://doi.org/10.1071/EN06025

16. Li Z, Peng H, Xie B, Liu C, Nie X, Wang D, Huang M, Xiao H, Shi L, Zhang XJ (2020) Dissolved organic matter in surface runoff in the Loess Plateau of China: The role of rainfall events and land-use. Hydrol Process 34:1446-1459. https://doi.org/10.1002/hyp.13660

17. Liu C, Fan C, Shen Q, Shao S, Zhang L, Zhou Q (2016) Effects of riverine suspended particulate matter on post-dredging metal re-contamination across the sediment-water interface. Chemosphere 144:2329-2335. https://doi.org/10.1016/j.chemosphere.2015.11.010

18. Liu C, Li Z, Berhe AA, Xiao H, Liu L, Wang D, Peng H, Zeng G (2019) Characterizing dissolved organic matter in eroded sediments from a loess hilly catchment using fluorescence EEM-PARAFAC and UV-Visible absorption: Insights from source identification and carbon cycling. Geoderma 334:3748. https://doi.org/10.1016/j.geoderma.2018.07.029

19. McKnight DM, Boyer EW, Westerhoff PK, Doran PT, Kulbe T, Andersen DT (2001) Spectrofluorometric characterization of dissolved organic matter for indication of precursor organic material and aromaticity. Limnol Oceanogr 46:38-48. https://doi.org/10.4319/lo.2001.46.1.0038

20. Meng F, Huang G, Yang X, Li Z, Li J, Cao J, Wang Z, Sun L (2013) Identifying the sources and fate of anthropogenically impacted dissolved organic matter (DOM) in urbanized rivers. Water Res 47:5027-5039. https://doi.org/10.1016/j.watres.2013.05.043

21. Murphy KR, Stedmon CA, Wenig P, Bro RJ (2014) OpenFluor-an online spectral library of auto-fluorescence by organic compounds in the environment. Anal Methods 6:658-661. https://doi.org/10.1039/c3ay41935e

22. Nishijima W, Speitel GE (2004) Fate of biodegradable dissolved organic carbon produced by ozonation on biological activated carbon. Chemosphere 56:113-119. https://doi.org/10.1016/j.chemosphere.2004.03.009

23. Ohno T (2002) Fluorescence Inner-Filtering Correction for Determining the Humification Index of Dissolved Organic Matter. Environ Sci Technol 36:742-746. https://doi.org/10.1021/es0155276

24. Osburn CL, Wigdahl CR, Fritz SC, Saros JE (2011) Dissolved organic matter composition and photoreactivity in prairie lakes of the US Great Plains. Limnol Oceanogr 56:2371-2390. https://doi.org/10.4319/lo.2011.56.6.2371

25. Rinot O, Borisover M, Levy GJ, Eshel G (2021) Fluorescence spectroscopy: A sensitive tool for identifying land-use and climatic region effects on the characteristics of water-extractable soil organic matter. Ecol Indic 121:107103. https://doi.org/10.1016/j.ecolind.2020.107103

26. Rosario-Ortiz FL, Korak JA (2017) Oversimplification of Dissolved Organic Matter Fluorescence Analysis: Potential Pitfalls of Current Methods. Environ Sci Technol 51:759-761. https://doi.org/10.1021/acs.est.6b06133

27. Sankar M, Dash P, Lu Y, Mercer AE, Turnage G, Shoemaker CM, Chen S, Moorhead RJ (2020) Land use and land cover control on the spatial variation of dissolved organic matter across 41 lakes in Mississippi, USA. Hydrobiologia 847:1159-1176. https://doi.org/10.1007/s10750-019-04174-0

28. Sankar MS, Dash P, Singh S, Lu Y, Mercer AE, Chen S (2019) Effect of photo-biodegradation and biodegradation on the biogeochemical cycling of dissolved organic matter across diverse surface water bodies. J Enviro Sci 77:130-147. https://doi.org/10.1016/j.jes.2018.06.021

29. Shang Y, Song K, Jacinthe PA, Wen Z, Zhao Y, Lyu L, Fang C, Li S, Liu G, Hou J, Zhang N (2021) Fluorescence spectroscopy of CDOM in urbanized waters across gradients of development/industrialization of China. J Hazard Mater 415:125630. https://doi.org/10.1016/j.jhazmat.2021.125630

30. Shi Y, Zhang L, Li Y, Zhou L, Zhou Y, Zhang Y, Huang C, Li H, Zhu G (2020) Influence of land use and rainfall on the optical properties of dissolved organic matter in a key drinking water reservoir in China. Sci Total Environ 699:134301. https://doi.org/10.1016/j.scitotenv.2019.134301

31. Stedmon CA, Markager S, Bro R (2003) Tracing dissolved organic matter in aquatic environments using a new approach to fluorescence spectroscopy. Mar Chem 82:239-254. https://doi.org/10.1016/S0304-4203(03)00072-0

32. Strobel BW, Hansen HCB, Borggaard OK, Andersen MK, Raulund-Rasmussen K (2001) Composition and reactivity of DOC in forest floor soil solutions in relation to tree species and soil type. Biogeochemistry 56:1-26. https://doi.org/10.1023/A:1011934929379

33. Tao P, Jin M, Yu X, Yu J, Zheng R (2021) Spatiotemporal variations in chromophoric dissolved organic matter (CDOM) in a mixed land-use river: Implications for surface water restoration. J Environ Manage 277:111498. https://doi.org/10.1016/j.jenvman.2020.111498

34. Wang H, Wang Y, Zhuang WE, Chen W, Shi W, Zhu Z, Yang L (2020) Effects of fish culture on particulate organic matter in a reservoir-type river as revealed by absorption spectroscopy and fluorescence EEM-PARAFAC. Chemosphere 239:124734.

https://doi.org/10.1016/j.chemosphere.2019.124734

35. Wang Y, Xu Y, Spencer RG, Zito P, Kellerman A, Podgorski D, Xiao W, Wei D, Rashid H, Yang YJ (2018) Selective leaching of dissolved organic matter from alpine permafrost soils on the Qinghai-Tibetan Plateau. J Geophy Res-Biogeo 123:1005-1016. https://doi.org/10.1002/2017JG004343

36. Wilson HF, Xenopoulos MA (2009) Effects of agricultural land use on the composition of fluvial dissolved organic matter. Nat Geosci 2:37-41. https://doi.org/10.1038/ngeo391

37. Worms IAM, Szigeti AG, Dubascoux S, Lespes G, Traber J, Sigg L, Slaveykova VI (2010) Colloidal organic matter from wastewater treatment plant effluents: Characterization and role in metal distribution. Water Res 44:340-350. https://doi.org/10.1016/j.watres.2009.09.037

38. Xu H, Xu M, Li Y, Liu X, Guo L, Jiang H (2018) Characterization, origin and aggregation behavior of colloids in eutrophic shallow lake. Water Res 142:176-186. https://doi.org/10.1016/j.watres.2018.05.059

Page 10/14 
39. Xu Q, Wang P, Shu W, Ding M, Zhang H (2021) Influence of landscape structures on river water quality at multiple spatial scales: A case study of the Yuan river watershed, China. Ecol Indic 121:107226. https://doi.org/10.1016/j.ecolind.2020.107226

40. Yan C, Yang Y, Zhou J, Nie M, Liu M, Hochella MF (2015) Selected emerging organic contaminants in the Yangtze Estuary, China: A comprehensive treatment of their association with aquatic colloids. J Hazard Mater 283:14-23. https://doi.org/10.1016/j.jhazmat.2014.09.011

41. Yan C, Liu H, Sheng Y, Huang X, Nie M, Huang Q, Baalousha M (2018) Fluorescence characterization of fractionated dissolved organic matter in the five tributaries of Poyang Lake, China. Sci Total Environ 637-638:1311-1320. https://doi.org/10.1016/j.scitotenv.2018.05.099

42. Yan C, Sheng Y, Ju M, Ding C, Li Q, Luo Z, Ding M, Nie M (2020) Relationship between the characterization of natural colloids and metal elements in surface waters. Environ Sci Pollut Res 27:31872-31883. https://doi.org/10.1007/s11356-020-09500-x

43. Zepp RG, Sheldon WM, Moran MA (2004) Dissolved organic fluorophores in southeastern US coastal waters: correction method for eliminating Rayleigh and Raman scattering peaks in excitation-emission matrices. Mar Chem 89:15-36. https://doi.org/10.1016/j.marchem.2004.02.006

44. Zhang Y, Liu M, Qin B, Feng S (2009) Photochemical degradation of chromophoric-dissolved organic matter exposed to simulated UV-B and natural solar radiation. Hydrobiologia 627:159-168. https://doi.org/10.1007/s10750-009-9722-z

45. Zhang YL, Qin BQ, Chen WM, Zhu GW (2005) A preliminary study of chromophoric dissolved organic matter (CDOM) in Lake Taihu, a shallow subtropical lake in China. Acta Hydroch Hydrob 33:315-323. https://doi.org/10.1002/aheh.200400585

46. Zhao X, Wei Y, Fan Y, Zhang F, Tan W, He X, Xi B (2018) Roles of bacterial community in the transformation of dissolved organic matter for the stability and safety of material during sludge composting. Bioresour Technol 267:378-385. https://doi.org/10.1016/j.biortech.2018.07.060

47. Zhou L, Zhou Y, Tang X, Zhang Y, Jeppesen E (2021) Biodegradable dissolved organic carbon shapes bacterial community structures and cooccurrence patterns in large eutrophic Lake Taihu. J Enviro Sci 107:205-217. https://doi.org/10.1016/j.jes.2021.02.011

48. Zhu M, Zhu G, Nurminen L, Wu T, Deng J, Zhang Y, Qin B, Ventelä AM (2015) The influence of macrophytes on sediment resuspension and the effect of associated nutrients in a shallow and large lake (Lake Taihu, China). PLoS ONE 10:e0127915. https://doi.org/10.1371/journal.pone.0127915

49. Zsolnay A, Baigar E, Jimenez M, Steinweg B, Saccomandi F (1999) Differentiating with fluorescence spectroscopy the sources of dissolved organic matter in soils subjected to drying. Chemosphere 38:45-50. https://doi.org/10.1016/S0045-6535(98)00166-0

\section{Tables}

Table 1 Statistical description and difference analysis of the fluorescence components for the water samples from the upstream, midstream, and downstream of Yuan River basin

\begin{tabular}{|c|c|c|c|c|c|c|c|c|c|c|}
\hline & & $\mathrm{C} 2-\mathrm{R}$ & C3-R & C3-F & $\mathrm{C} 1 \%-\mathrm{F}$ & $\mathrm{C} 1 \%-\mathrm{U}$ & $\mathrm{C} 2 \%-\mathrm{F}$ & $\mathrm{C} 2 \%-\mathrm{U}$ & $\mathrm{C} 3 \%-\mathrm{R}$ & $\mathrm{C} 3 \%-\mathrm{F}$ \\
\hline & upstream & $\begin{array}{l}0.29 \pm 0.06 \\
a\end{array}$ & $\begin{array}{l}0.11 \pm 0.05 \\
\mathrm{a}\end{array}$ & $\begin{array}{l}0.11 \pm 0.05 \\
a\end{array}$ & $\begin{array}{l}43.36 \pm 4.19 \\
a\end{array}$ & $\begin{array}{l}38.94 \pm 13.85 \\
\mathrm{a}\end{array}$ & $\begin{array}{l}41.73 \pm 4.50 \\
\text { a }\end{array}$ & $\begin{array}{l}37.22 \pm 9.00 \\
\text { a }\end{array}$ & $\begin{array}{l}14.28 \pm 5.03 \\
a\end{array}$ & $\begin{array}{l}14.90 \pm 0.56 \\
\mathrm{a}\end{array}$ \\
\hline \multirow[t]{3}{*}{ M } & midstream & $\begin{array}{l}0.36 \pm 0.08 \\
a b\end{array}$ & $\begin{array}{l}0.15 \pm 0.03 \\
a b\end{array}$ & $\begin{array}{l}0.14 \pm 0.02 \\
a b\end{array}$ & $\begin{array}{l}49.67 \pm 1.86 \\
b\end{array}$ & $\begin{array}{l}52.86 \pm 2.04 \\
\text { b }\end{array}$ & $\begin{array}{l}31.79 \pm 1.42 \\
\text { b }\end{array}$ & $\begin{array}{l}29.23 \pm 1.11 \\
\text { b }\end{array}$ & $\begin{array}{l}16.37 \pm 1.86 \\
a b\end{array}$ & $\begin{array}{l}18.54 \pm 1.24 \\
\mathrm{ab}\end{array}$ \\
\hline & downstream & $\begin{array}{l}0.38 \pm 0.05 \\
b\end{array}$ & $\begin{array}{l}0.17 \pm 0.03 \\
\mathrm{~b}\end{array}$ & $\begin{array}{l}0.24 \pm 0.13 \\
b\end{array}$ & $\begin{array}{l}41.43 \pm 4.87 \\
\mathrm{a}\end{array}$ & $\begin{array}{l}48.04 \pm 2.73 \\
a b\end{array}$ & $\begin{array}{l}34.83 \pm 2.76 \\
\text { b }\end{array}$ & $\begin{array}{l}31.67 \pm 1.54 \\
a b\end{array}$ & $\begin{array}{l}18.62 \pm 1.75 \\
b\end{array}$ & $\begin{array}{l}23.75 \pm 6.67 \\
b\end{array}$ \\
\hline & upstream & $\begin{array}{l}0.28 \pm 0.03 \\
a\end{array}$ & & & $\begin{array}{l}44.06 \pm 9.61 \\
a b\end{array}$ & & $\begin{array}{l}42.67 \pm 11.14 \\
a b\end{array}$ & & & $\begin{array}{l}13.26 \pm 1.88 \\
a\end{array}$ \\
\hline $\mathrm{T}$ & midstream & $\begin{array}{l}0.34 \pm 0.12 \\
a b\end{array}$ & & & $\begin{array}{l}35.16 \pm 7.00 \\
\text { a }\end{array}$ & & $\begin{array}{l}51.71 \pm 9.06 \\
\text { a }\end{array}$ & & & $\begin{array}{l}13.13 \pm 3.65 \\
a\end{array}$ \\
\hline & downstream & $\begin{array}{l}0.42 \pm 0.11 \\
b\end{array}$ & & & $\begin{array}{l}48.36 \pm 9.15 \\
b\end{array}$ & & $\begin{array}{l}35.39 \pm 8.72 \\
\text { b }\end{array}$ & & & $\begin{array}{l}16.26 \pm 1.38 \\
b\end{array}$ \\
\hline
\end{tabular}

Table 2 Interpretation of the spectral parameters by land-use types for the water samples from Yuan River basin (\%) 


\begin{tabular}{|c|c|c|c|c|c|c|c|c|}
\hline & & All & $\mathrm{T}$ & M & & & All & $\mathrm{T}$ \\
\hline \multirow[t]{3}{*}{ 500m (spectral parameters) } & RDA1 & 9.1 & 10.1 & 14.6 & \multirow[t]{3}{*}{$500 \mathrm{~m}(\mathrm{R})$} & RDA1 & 18.1 & 13.5 \\
\hline & RDA2 & 1.2 & 1.1 & 0.5 & & RDA2 & 1.5 & 1.6 \\
\hline & total interpretation & 10.3 & 11.3 & 15.3 & & total interpretation & 19.6 & 15.1 \\
\hline \multirow[t]{3}{*}{$1000 \mathrm{~m}$ (spectral parameters) } & RDA1 & 6.3 & 16.6 & 1.0 & \multirow[t]{3}{*}{$500 \mathrm{~m}(\mathrm{~F})$} & RDA1 & 27.2 & 31.1 \\
\hline & RDA2 & 0.1 & 0.7 & 0.3 & & RDA2 & 0.3 & 0.3 \\
\hline & total interpretation & 6.4 & 17.3 & 1.3 & & total interpretation & 27.7 & 31.6 \\
\hline \multirow[t]{3}{*}{ 500m (UV-vis) } & RDA1 & 9.1 & 10.2 & 14.6 & \multirow[t]{3}{*}{$1000 m(R)$} & RDA1 & 5.0 & 12.2 \\
\hline & RDA2 & 1.2 & 1.1 & 0.4 & & RDA2 & 1.2 & 2.4 \\
\hline & total interpretation & 10.3 & 11.3 & 15.1 & & total interpretation & 6.3 & 14.7 \\
\hline \multirow[t]{3}{*}{ 1000m (UV-vis) } & RDA1 & 6.3 & 16.7 & 1.0 & \multirow[t]{3}{*}{$1000 \mathrm{~m}(\mathrm{~F})$} & RDA1 & 17.9 & 42.7 \\
\hline & RDA2 & 0.1 & 0.7 & 0.2 & & RDA2 & 0.1 & 0.3 \\
\hline & total interpretation & 6.4 & 17.4 & 1.2 & & total interpretation & 18.0 & 43.0 \\
\hline \multirow[t]{3}{*}{ 500m (fluorescence) } & RDA1 & 13.3 & 13.9 & 46.2 & & & & \\
\hline & RDA2 & 0.6 & 0.9 & 4.2 & & & & \\
\hline & total interpretation & 14.0 & 14.8 & 51.0 & & & & \\
\hline \multirow[t]{3}{*}{ 1000m (fluorescence) } & RDA1 & 1.8 & 3.5 & 22.8 & & & & \\
\hline & RDA2 & 0.3 & 0.8 & 0.5 & & & & \\
\hline & total interpretation & 2.1 & 4.3 & 23.4 & & & & \\
\hline
\end{tabular}

Figures
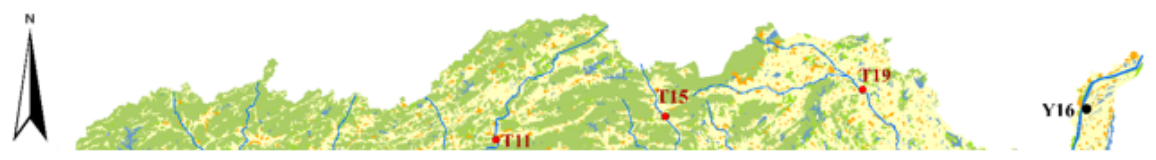

Figure 1

Distribution of land use and sampling points in Yuan River basin 


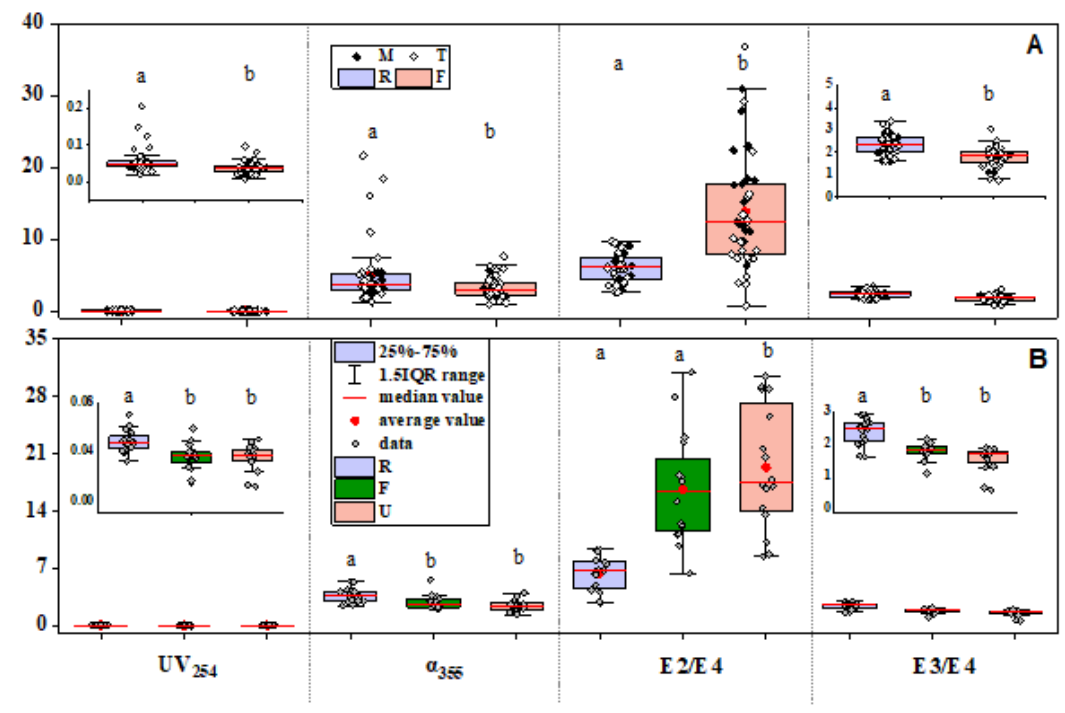

Figure 2

UV-vis parameters of water samples from the Yuan River basin (letters in the figure indicate the significant differences, $P<0.05$ )

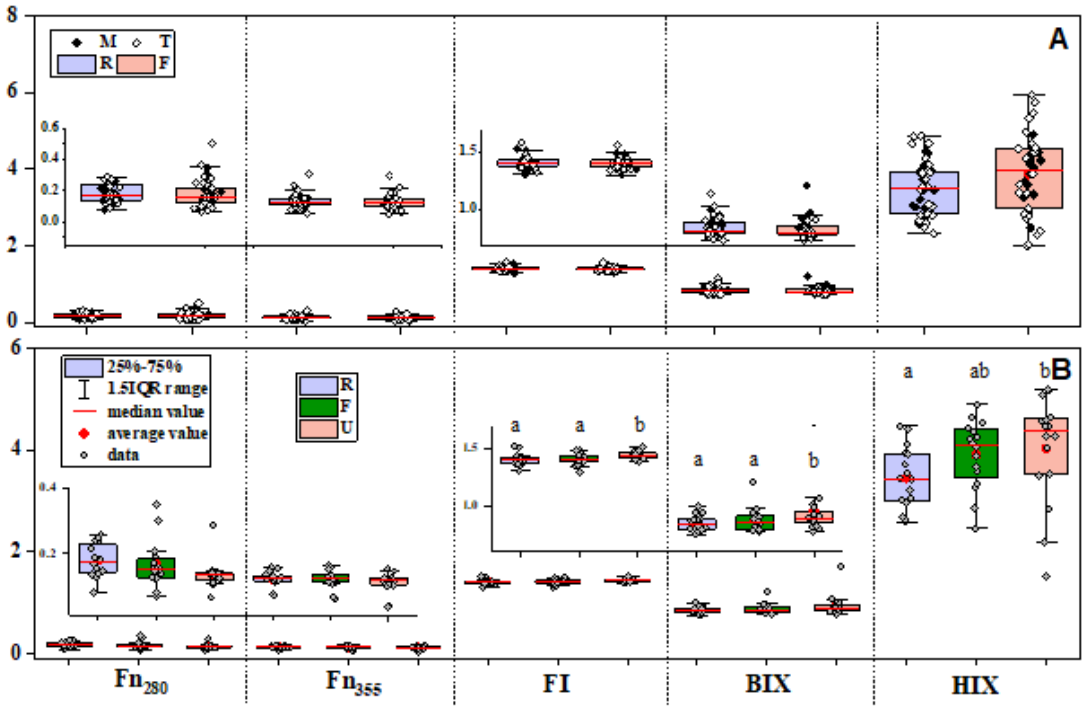

Figure 3

Fluorescence indices of water samples from the Yuan River basin 


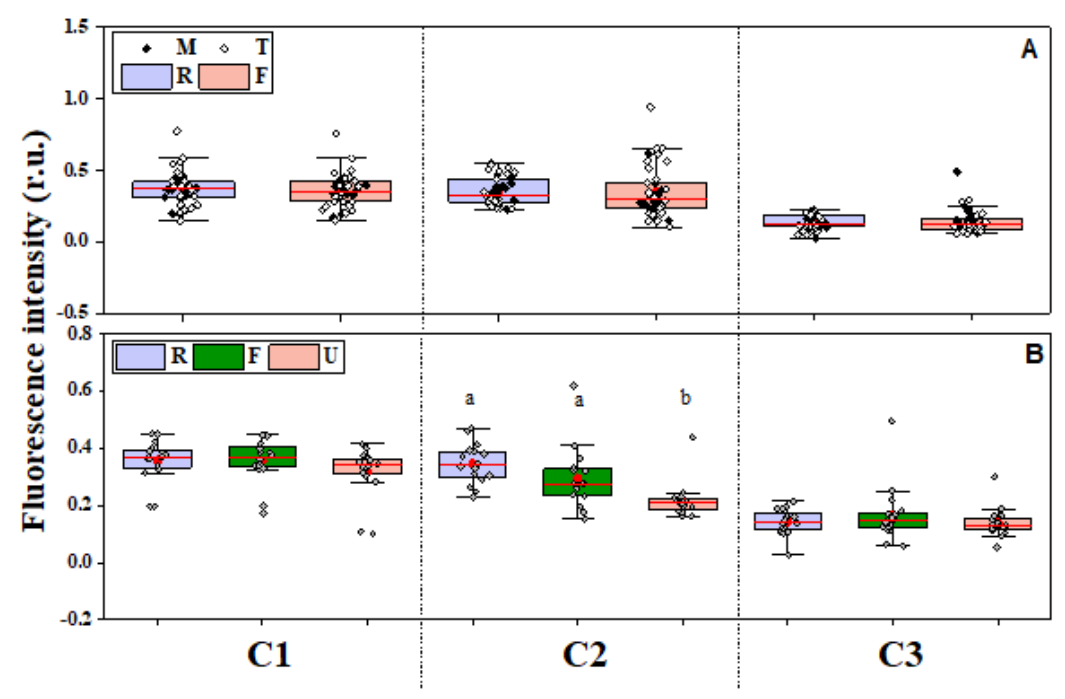

Figure 4

Fluorescence intensity of $\mathrm{C} 1-\mathrm{C} 3$ for the water samples from the Yuan River basin

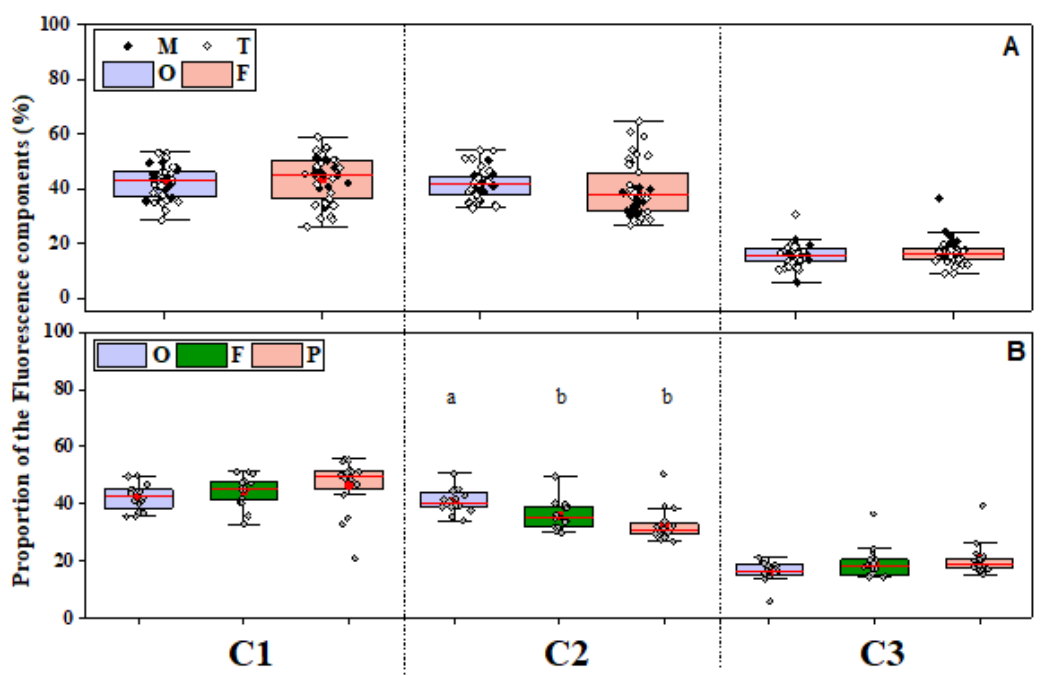

Figure 5

Proportion of $\mathrm{C} 1-\mathrm{C} 3$ for the water samples from the Yuan River basin

\section{Supplementary Files}

This is a list of supplementary files associated with this preprint. Click to download.

- renamed276d2.docx 